\title{
Comparison between infaunal communities of the deep floor and edge of the Tonga Trench: Possible effects of differences in organic matter supply
}

\author{
Daniel Leduc ${ }^{\mathrm{a}, *}$, Ashley A. Rowden ${ }^{\mathrm{a}}$, Ronnie N. Glud ${ }^{\mathrm{b}, \mathrm{c}, \mathrm{d}, \mathrm{e}}$, Frank Wenzhöfer ${ }^{\mathrm{f}}$, \\ Hiroshi Kitazato ${ }^{\mathrm{g}}$, Malcolm R. Clark $^{\text {a }}$ \\ ${ }^{a}$ National Institute of Water and Atmospheric Research, Private Bag 14-901, Wellington, New Zealand \\ ${ }^{\mathrm{b}}$ University of Southern Denmark, Nordic Centre for Earth Evolution, Odense M-5230, Denmark \\ ${ }^{\mathrm{c}}$ Aarhus University, Arctic Research Center, Aarhus C-8000, Denmark \\ d Scottish Association for Marine Science, Scottish Marine Institute, Oban PA37 1QA, UK \\ e Greenland Climate Research Centre, Greenland Institute of Natural Resources, Nuuk 3900, Greenland \\ ${ }^{\mathrm{f}}$ Max Planck Institute for Marine Microbiology, Celsiusstr 1, d-28359, Bremen 28359, Germany \\ gapan Agency for Marine-Earth Science and Technology, Institute of Biogeosciences, Yokosuka, Kanagawa 237-0061, Japan
}

\section{A R T I C L E I N F O}

\section{Article history:}

Received 17 September 2015

Received in revised form

15 November 2015

Accepted 18 November 2015

Available online 2 December 2015

\section{Keywords:}

Southwest Pacific

Hadal

Meiofauna

Food availability

Community structure

Biodiversity

Bioturbation

\begin{abstract}
A B S T R A C T
Hadal trenches are characterised by environmental conditions not found in any other environment, thereby providing new opportunities to understand the processes that shape deep-sea benthic communities. Technological advances have led to an increase in the number of investigations in hadal trenches over the last two decades. However, more quantitative samples including the deepest parts of trenches is needed to better understand trends in benthic diversity, abundance, biomass and community structure in these extreme habitats, and how these may be shaped by environmental and/or evolutionary factors. In this study, we describe and compare the abundance, biomass, vertical distribution in the sediment, diversity, and community structure of nematodes and other infauna in sediments from the Horizon Deep ( $\sim 10800 \mathrm{~m}$ ) in the Tonga Trench and a site on the edge of the trench $(\sim 6250 \mathrm{~m})$. Mean nematode abundance was six times greater at the Horizon Deep site $\left(387\right.$ ind $\left.10 \mathrm{~cm}^{-2}\right)$ than at the trench edge site ( 65 ind. $10 \mathrm{~cm}^{-2}$ ). A similar pattern was observed for biomass ( $15 \mathrm{vs} 2 \mu \mathrm{gDW} 10 \mathrm{~cm}^{-2}$, respectively), which likely resulted from elevated organic matter supply at the Horizon Deep site. There was no significant difference in nematode species richness between the two sites, but diversity measured using rarefaction was significantly greater at the trench edge site than at the Horizon Deep site [ES(20); 13.8 vs 7.8]. Dominance was much more pronounced in the Horizon Deep, which may be due to competitive exclusion by a small number of opportunistic species. Nematode community structure differed significantly both between sites and among sediment depth layers. The presence of subsurface peaks in pigment concentrations, bacteria abundance, and nematode abundance at the Horizon Deep site is consistent with a recent turbidite event, and may also reflect high rates of bioturbation by larger fauna resulting from high food availability. Determining the relative influences of different environmental factors on hadal trench benthic communities will require further investigation based on quantitative samples encompassing the trench axis as well as the oceanic and continental slopes.
\end{abstract}

(c) 2015 Elsevier Ltd. All rights reserved.

\section{Introduction}

The hadal zone ( $>6000 \mathrm{~m}$ depth) represents $\sim 1-2 \%$ of the total seafloor area, but accounts for almost half of the ocean's depth range. Oceanic trenches are the dominant habitat within this bathymetric zone, yet quantitative studies of their benthic communities and the environmental forces that shape them are

\footnotetext{
* Corresponding author.
}

relatively rare (Jamieson et al., 2010). Trenches have often been described as depocentres of organic matter based mainly on observations of high abundance and biomass of infauna, deposit feeders, and/or mobile scavenging fauna in the deepest parts of trenches relative to shallower areas of the trench or the abyssal plain (e.g., Belyaev, 1972; Jumars and Hessler, 1976; Tietjen et al., 1989; Blankenship et al., 2006; but see Shirayama (1984a) and Itoh et al. (2011)). A recent investigation in the Challenger Deep, the world's deepest point in the Mariana Trench, provided direct evidence for elevated deposition of organic matter and intensified 
microbial metabolism at the axis of the trench relative to the edge of the trench (Glud et al., 2013). Together, these separate lines of evidence suggest a link between elevated food supply and high faunal standing stock at the greatest depths of hadal trenches.

Whilst benthic communities in hadal trenches are generally rich in terms of abundance and biomass, their species richness is low. The early analyses of trawl samples obtained mainly during the Vityaz and Galathea expeditions prior to 1960 led Wolff (1960) and Belyaev (1972) to conclude that the benthic communities of hadal trenches show trends of decreasing species richness with depth, a pattern associated with increased dominance of a small number of species (Belyaev, 1972). Since then a number of studies conducted on the diversity of hadal trench benthic communities have provided support for a trend of decreasing diversity with depth. An investigation of nematodes in Puerto Rico Trench and neighbouring abyssal plain and continental slope showed that richness was lowest in the deepest part of the trench, a pattern that was ascribed to low food availability (i.e., concentration of phytodetritus in the sediments) and homogeneous fine sediments in the trench (Tietjen, 1989). Decreasing food availability was also considered the most likely factor explaining a pattern of decreasing species richness of bait-attending amphipods in both the Peru-Chile and Kermadec trenches from ca. 6000 to $8000 \mathrm{~m}$ depth (Fujii et al., 2013). A similar bathymetric pattern was found for nematode diversity in the Peru-Chile Trench by Gambi et al. (2003). In this case, high food availability was suggested as the most likely factor leading to low diversity in the trench (Danovaro et al., 2002), even though measures of food availability did not differ markedly between the trench and adjoining continental slope study sites. Similarly, no obvious differences in food availability were observed between bathyal and hadal environments in the Kuril Trench region where harpacticoid genus richness declined from 2000 to $7000 \mathrm{~m}$ depth (Kitahashi et al., 2013). Instead diversity was correlated with sediment sorting, a measure of habitat heterogeneity (Kitahashi et al., 2013). The available evidence therefore suggests that low diversity at the deep trench floor is not necessarily dependent on food availability, and may be influenced by the physical characteristics of the sediment (Tietjen 1989; Kitahashi et al., 2013) as well as other factors such as physical disturbance and low regional diversity (Gambi et al., 2003) which have not yet been investigated directly.

Benthic communities of hadal trenches are distinct from those of the abyssal plain (Jamieson et al., 2011; Fujii et al., 2013; Kitahashi et al., 2013; Gallo et al., 2015). The transition in community structure between the two environments was originally thought to be gradual (Wolff, 1970), but more recent evidence from an analysis of scavenging amphipod data from the Kermadec Trench region suggests the presence of an ecotone at the abyssal-hadal boundary (Jamieson et al., 2011). Data for harpacticoid copepods from the Kuril Trench region also suggests that trench floor communities are substantially different from those at sites on the trench slope and abyssal plain (3030-5730 m) (Kitahashi et al., 2013), and Gallo et al. (2015) have observed differences in community structure between abyssal and hadal mega-fauna in the New Britain Trench. This shift in community structure is thought to be associated with environmental variables (e.g. habitat heterogeneity, food availability) that change with the relatively sharp transition from shallow-sloping abyssal plain to the steep and unstable topography of trenches (Jamieson et al., 2011; Gallo et al., 2015). Because of the complex and varied topography of trenches, and differences in their geographical location and associated environmental setting, the precise depth at which this transition occurs is expected to be trench-specific (Fujii et al., 2013; Schmidt and Martinez-Arbizu, 2015), and may vary within trenches.

Despite some emerging hadal paradigms for biodiversity patterns, more evidence, based on quantitative samples including the deepest parts of trenches, is needed to better understand benthic diversity, abundance, biomass and community structure trends in these extreme habitats, and how these may be shaped by environmental and/or evolutionary factors (Jamieson, 2015). Meiofauna constitute the most abundant group of metazoans in marine sediments (Giere, 2009), and become increasingly dominant in deeper waters as organic matter availability decreases, whereas the larger macro- and megafauna become relatively less abundant (Rex et al., 2006). Meiofauna are therefore ideal organisms for the study of benthic community trends across all deep-sea environments (Vanreusel et al., 2010). Diverse nematode communities have been found in the Puerto Rico Trench (Tietjen, 1989), PeruChile Trench (Gambi et al., 2003), and South Sandwich Trench (Vanhove et al., 2004) between 6316 and $8380 \mathrm{~m}$ depths, and nematodes were encountered in a trawl sample at 10 415-10 $687 \mathrm{~m}$ in Tonga Trench during the Vityaz expedition in 1957 (Belyaev, 1972), suggesting that they thrive in the deepest parts of the oceans.

The vertical distribution of meiofauna in the sediments is affected by a variety of factors, including food availability, oxygen and sulphide concentrations, and macrofaunal activity (Giere, 2009). Meiofauna are typically concentrated in the top few centimetres of sediment where food is usually most abundant and oxygen levels relatively high (Meyers et al., 1987); this kind of distribution is common in abyssal sediments (Shirayama, 1984b; Alongi, 1992; Radziejewska, 2002). Data from the deepest parts of the Ogasawara, Kuril, Ryuku, and Puerto Rico trenches indicate that a similar distribution pattern is also present for meiofauna at hadal depths (Shirayama, 1984b; Tietjen et al., 1989; Itoh et al., 2011). However among the meiofauna, nematodes appear to be least affected by low oxygen concentrations and their distribution often extend to hypoxic layers where they can presumably exploit available food resources (Moodley et al., 2000; Nomaki et al., in press). Nematodes may also be transported deep into the sediments by the bioturbation activity of macrofauna (Moodley et al., 2000), or through physical disturbance (Leduc and Pilditch, 2013). The vertical distribution of nematodes in the sediment may therefore provide an indicator for the degree of vertical sediment mixing and burial of organic matter occurring as a result of bioturbation or physical processes (such as turbidite flow) thought to be relatively common in trenches (Lambshead et al., 2001; Oguri et al., 2013).

The Horizon Deep in the Tonga Trench is the second deepest point after the Challenger Deep in the Mariana Trench (Belyaev, 1989). Recent work on the Challenger Deep and other 'deeps' within the Mariana Trench has led to the recognition of the deepest points of the trenches as potentially unique, important, and well-defined ecological habitats, thereby justifying detailed study of these extreme ecosystems in the context of the wider trench environment (Jamieson, 2015). Whilst Horizon Deep has been sampled using trawls (Belyaev, 1989) and baited traps (Blankenship 2006), no quantitative benthic sampling has yet been conducted. As part of the QUELLE (Quest for the Limit of Life) aroundthe-world voyage in 2013, the Tonga Trench was sampled to "shed light on the habitable limits of life and its unique survival strategies" (https://www.jamstec.go.jp/quelle2013/e/pdf/brochure.pdf). The main objectives of the present study were to describe and compare the abundance, biomass, vertical distribution in the sediment, diversity, and community structure of nematodes and other infauna between the Horizon Deep and a site on the edge of Tonga Trench based on quantitative sediment core samples. We test two hypotheses: that elevated food availability at the Horizon Deep site, compared to the trench edge site, would lead to an infaunal community characterised by high abundance and biomass, low diversity and distinct community structure; and secondly that differences in sediment granulometry or higher levels of 
bioturbation and/or physical disturbance at the Horizon Deep site, compared to the trench edge site, could influence diversity and community structure patterns and would lead to deeper penetration of infauna into the sediment at the Horizon Deep site.

\section{Methods}

\subsection{Sampling}

The Tonga Trench extends from approximately $15^{\circ} \mathrm{S}$ to $25^{\circ} \mathrm{S}$ in the Southwest Pacific Ocean (Fig. 1A); the deepest point of the trench, known as the Horizon Deep, lies $10882 \mathrm{~m}$ beneath the ocean surface. Samples were obtained from the Horizon Deep and at a nearby site on the edge of the trench (Fig. 1B and C) during Japan Agency for Marine-Earth Science and Technology (JAMSTEC) cruise YK13-10 in October 2013 (http://www.godac.jamstec.go.jp/ catalog/data/doc_catalog/media/YK13-10_all.pdf). Sediment cores were obtained from the Horizon Deep site during two deployments (at 10811 and $10817 \mathrm{~m}$ depth, and $300 \mathrm{~m}$ apart) of a deepsea camera system fitted with three core samplers (Murashima et al., 2009). A total of four cores (two from each deployment) were processed for infauna from Horizon Deep. An additional four sediment cores were obtained at the shallower site on the edge of the trench $(6250 \mathrm{~m})$ using the manned submersible SHINKAI 6500 (Dive \#1370). All cores were subsampled for faunal analyses using a subcore of internal diameter $26 \mathrm{~mm}$ taken to a depth of $10 \mathrm{~cm}$. All subcores (eight in total) were sliced into $0-1,1-2,2-3,3-4,4-5$ and $5-10 \mathrm{~cm}$ layers and fixed in $10 \%$ buffered formalin, except for

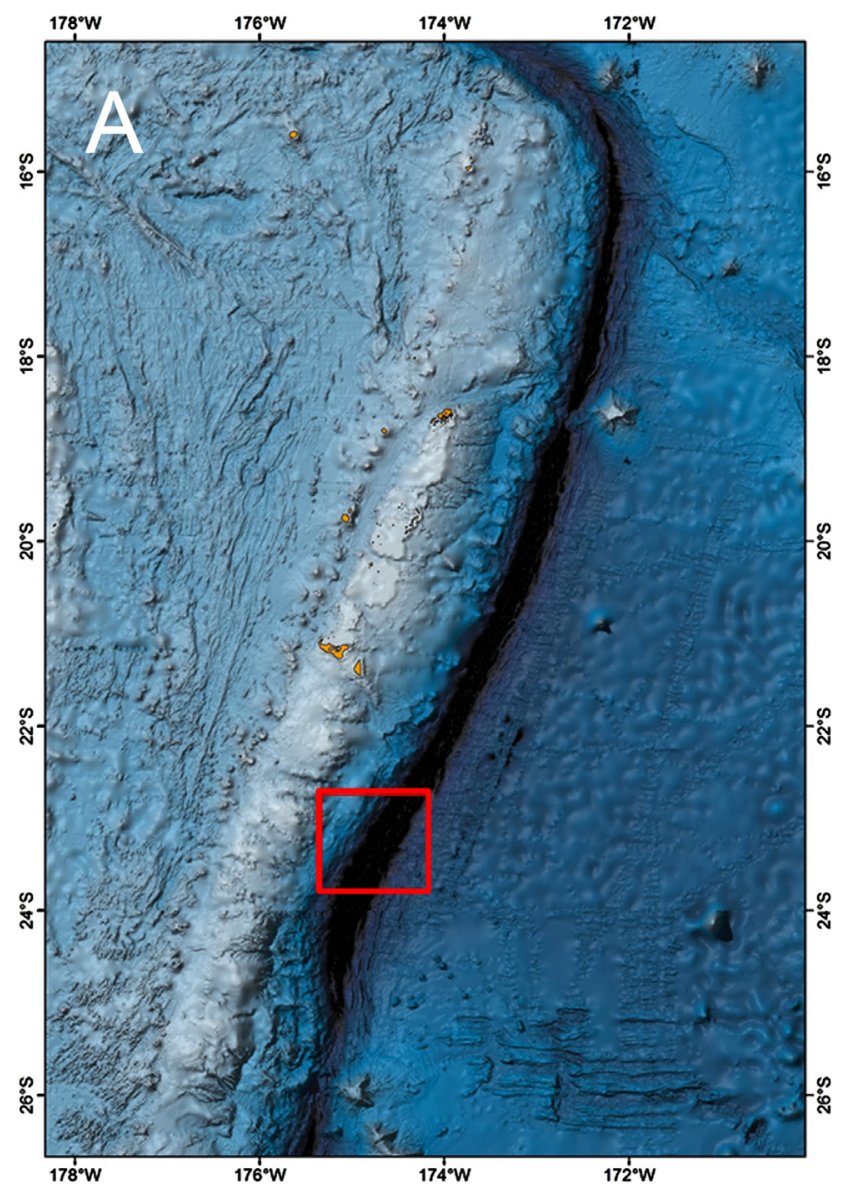

one subcore from the $6250 \mathrm{~m}$ site which was only sliced into $0-1$, $1-5$, and $5-10 \mathrm{~cm}$ layers due to the unconsolidated nature of the sediments. Sediments left in the cores following meiofauna sampling were fixed in $10 \%$ buffered formalin and used for grain size analyses (0-10 cm layer, two cores from each site).

\subsection{Infauna}

Infauna living in deep-sea environments tend to be small relative to fauna in shallow environments and are therefore easily overlooked or damaged during processing (Leduc et al., 2010). The methodology adopted here was used to minimise the number of specimens missed or damaged, whilst maximising the number of specimens that can be identified using a high magnification compound microscope. In the laboratory, samples were rinsed on a $20 \mu \mathrm{m}$ sieve (no upper mesh was used), and the fauna was extracted from the remaining sediments by Ludox flotation (Somerfield and Warwick, 1996). Extracted samples were stained with Rose Bengal and transferred to pure glycerol in a cavity block (Somerfield and Warwick, 1996). Samples in cavity blocks were inspected using a dissecting microscope (40-50 $\times$ magnification) and nematodes and other fauna were picked out and mounted on separate slides in glycerol (heretofore referred to as "faunal slides"). After scanning the entire cavity block for the presence of fauna, the search for specimens was continued until five minutes elapsed without finding specimens. The remaining material in the cavity block was transferred on a slide and spread over an area of $\sim 15 \times 50 \mathrm{~mm}^{2}$ and inspected again at the same magnification for the presence of fauna (the search for nematode specimens was
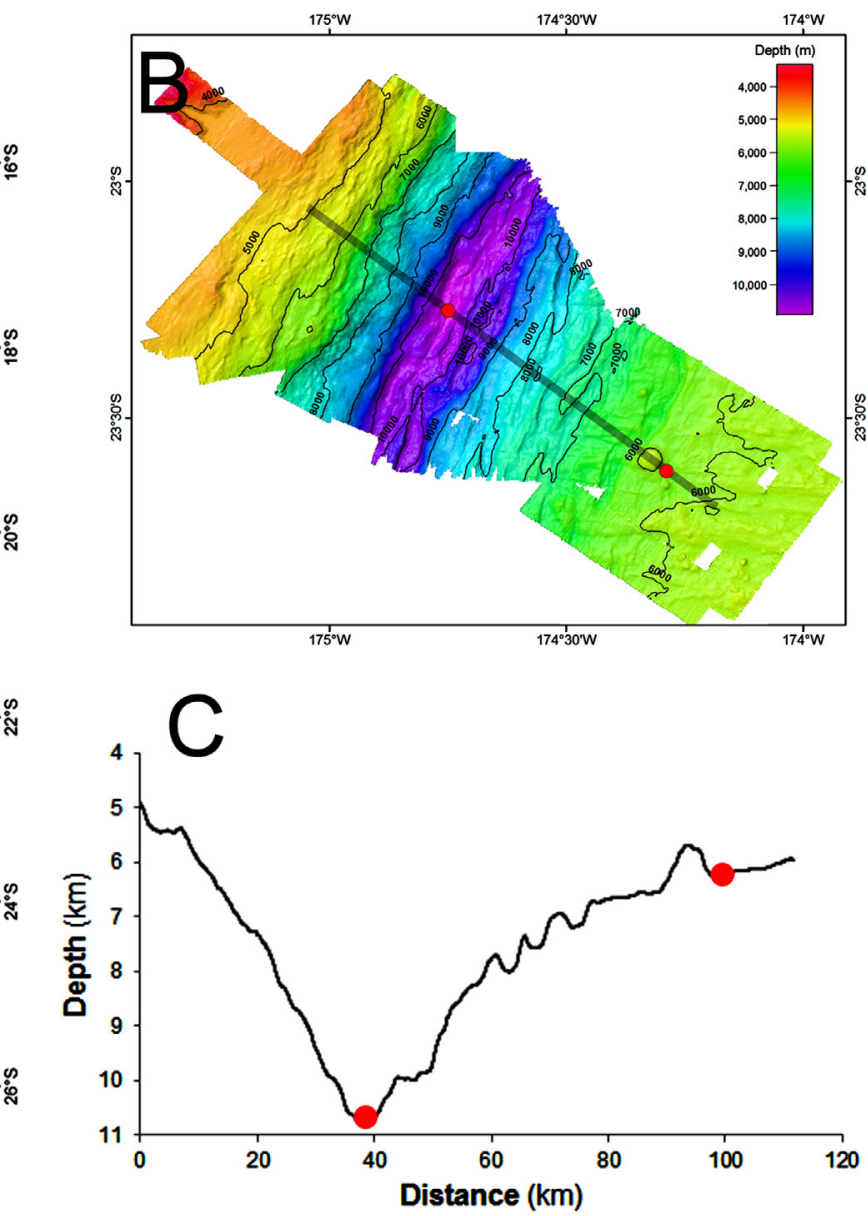

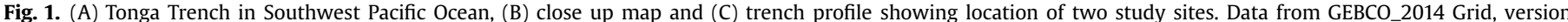
20150318 (map A) and National Geophysical Data Center at NOAA (map B and profile C). 
conducted as above); any remaining fauna were mounted onto separate faunal slides. The material remaining on the slide (i.e., organic debris in glycerol) was sealed using paraffin wax (heretofore referred to as "bulk slides"; Somerfield and Warwick, 1996). The abundance and diversity of nematodes and other fauna were determined by counting and identifying all specimens on faunal slides and any individuals remaining on bulk slides. All nematodes were identified to putative species (whenever possible) using the descriptions in Warwick et al. (1998) and Schmidt-Rhaesa ((ed.), 2014), as well as the primary literature. Species diversity was compared using species richness, expected number of species in a sample of 20 individuals [ES(20), based on the smallest number of individuals identified in a single sample; Hurlbert, 1971], and by building k-dominance plots to display the cumulative proportion abundance against the log species rank (Clarke and Warwick, 2001). The methods used for sample extraction were not suitable for quantifying the abundance of foraminiferans and gromids, and we therefore report only on the metazoan fauna.

Infaunal body volumes were estimated from length and maximum body width measurements obtained by video image analysis of all individuals (Nodder et al., 2003; Grove et al., 2006). Body volumes were converted to dry weight (DW) based on a relative density of 1.13 and a dry:wet weight ratio of 0.25 (Feller and Warwick, 1988).

\subsection{Sediment characteristics}

Sediment samples were first left to settle for three days in the laboratory, then the overlying liquid was carefully syphoned out and the sediments homogenised prior to subsampling. Three subsamples were obtained from each sample to obtain average values. Grain size parameters were determined using Sedigraph techniques (Nodder et al., 2003). Sediment particle size diversity was estimated based on the relative abundance of nine size classes (from clay to medium sand) present in the samples using the method of Etter and Grassle (1992).

\subsection{Statistical analyses}

Analyses of univariate and multivariate data were conducted using the PERMANOVA routine in PRIMER6 (PRIMER-E Ltd., Plymouth, UK; Anderson et al., 2008). Similarity matrices for univariate variables (i.e., abundance, biomass and diversity) were built using Euclidean distance of untransformed data, and similarity matrices for multivariate data (nematode community structure only) were built using the Bray-Curtis similarity measure of square root-transformed data (Anderson et al., 2008, 2011). Analyses of nematode species community structure were conducted using a repeated measure design (to take into account the lack of independence between sediment depths within each subcore) using the fixed factor Site (two levels: trench edge vs Horizon Deep), the fixed factor Sediment depth (six levels: $0-1,1-2$, $2-3,3-4,4-5$, and $5-10 \mathrm{~cm}$ ), and with replicate cores nested within Site but not Sediment depth (Quinn and Keough, 2009). The square root of estimates of components of variation $(\sqrt{ } \mathrm{ECV})$ were used to compare the amount of variation attributable to different terms in the PERMANOVA model, and the PERMDISP routine was used to test for differences in multivariate dispersion between the sites (Anderson et al., 2008). P-values were obtained using 999 permutations. The SIMPER routine in PRIMER was used to identify the species contributing most to within-group similarity and to quantify dissimilarity between and within sites (Clarke and Warwick, 2001). Patterns in nematode community structure were visualised using a multidimensional (MDS) scaling ordination plot (Clarke and Warwick, 2001).

\section{Results}

\subsection{Infauna community characteristics}

Mean infaunal abundance (for the upper $10 \mathrm{~cm}$ of sediment) at the Horizon Deep site (range: $229-511$ ind. $10 \mathrm{~cm}^{-2}$ ) was six times greater than at the trench edge site $\left(45-90\right.$ ind. $\left.10 \mathrm{~cm}^{-2}\right)$. This pattern was driven mainly by nematodes, which were dominant at both sites and represented $96 \%$ of total infaunal abundance on average. Of the six other faunal taxa present, harpacticoid copepods were the next most abundant taxon (2\% of total abundance), followed by mites (1\%). Variability in infaunal biomass was high due to the presence of a small number of relatively large bivalves and polychaetes, and, to a lesser extent, harpacticoid copepods. Bivalves and polychaetes combined accounted for an average of $11 \%$ and $87 \%$ of total infaunal biomass at the trench edge and Horizon Deep sites, respectively. When these two taxa are excluded, mean infaunal biomass at the Horizon Deep site was three times greater than at the trench edge site (Table 1). Nematode abundance and biomass were six times greater at the Horizon Deep site than at the trench edge site (Fig. 2).

Only a small number of non-nematode taxa were observed in the samples, and no meaningful analysis of their vertical distribution in the sediments could be conducted. The vertical distribution of nematodes were markedly different between the sites: almost half of all individuals were concentrated in the top one centimetre of sediment at the trench edge site, whereas most individuals were found in the deepest sediment layer $(5-10 \mathrm{~cm})$ at the Horizon Deep site (Fig. 3). This pattern was consistent across all four subcores that were analysed from each site.

A total of 55 nematode species belonging to 31 genera were identified from the samples. The total number of species from the trench edge and Horizon Deep sites was similar (32 and 36, respectively). Nematode species richness was generally higher in Horizon Deep cores relative to trench edge cores, but the difference was not significant (PERMANOVA, $P=0.14$; Fig. 2). Species diversity $[E S(20)]$ was significantly greater at the trench edge site (13.8) than at the Horizon Deep site $(7.8 ; P<0.01)$. This difference reflects the greater dominance of a few abundant species in the Horizon Deep than at the edge of the trench (Fig. 4).

The two dimensional MDS plot showed a clear difference in community structure between sites (Fig. 5). There was a significant effect of Site, Sediment depth, and their interactions on nematode community structure (PERMANOVA, $P<0.05$; Table 2), with the significant interaction effect reflecting the inconsistent effect of sediment depth at each site. Comparing the estimates of components of variation $(\sqrt{ } \mathrm{ECV})$ shows that the amount of variation in nematode community structure explained by sediment depth was less than half that of the variation between sites $(\sqrt{ } \mathrm{ECV}=16.3$ vs 36.6 , respectively). Average within-site dissimilarity was $34.0 \%$ and $49.8 \%$ at the Horizon Deep and trench edge sites, respectively, whereas average between-site dissimilarity was $82.4 \%$. Comparison of the mean deviation from centroid shows that within-site variability in community structure was significantly greater at the trench edge than Horizon Deep site (30.6 vs 20.7, respectively; PERMDISP, $P<0.05$ ). There was limited overlap in species composition between sites with about one quarter of species (13 out of 55) found at both locations.

The nematode community at the trench edge site was characterised mainly by Monhystrella sp. A and sp. E, Manganonema sp. E, Aegialoalaimus sp. A, and Desmolorenzenia sp. A, whereas Monhystrella sp. A and sp. B, Manganonema kitasatoi, Lamyronema horizonensis and Desmoscolex sp. A dominated at the Horizon Deep site (Table 3). Vertical shifts in community structure within the sediment were observed at both sites due to gradual changes in dominant species (Fig. 5 and Supplement Table 1). At the trench edge site, different Monhystrella species dominated surface and 
Table 1

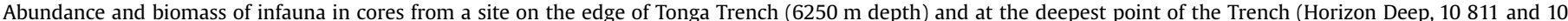
$817 \mathrm{~m}$ ).

\begin{tabular}{|c|c|c|c|c|c|c|c|c|}
\hline & \multicolumn{4}{|c|}{ Trench edge } & \multicolumn{4}{|c|}{ Horizon Deep } \\
\hline & \multicolumn{4}{|l|}{$6250 \mathrm{~m}$} & \multicolumn{2}{|l|}{$10,811 \mathrm{~m}$} & \multicolumn{2}{|c|}{$10,817 \mathrm{~m}$} \\
\hline & Core 2 & Core 3 & Core 4 & Core 9 & Core 1 & Core 3 & Core 1 & Core 2 \\
\hline \multicolumn{9}{|l|}{ Abundance $\left(10 \mathrm{~cm}^{-2}\right)$} \\
\hline Nematodes & 86.5 & 63.9 & 54.5 & 43.2 & 460.6 & 221.8 & 498.2 & 325.2 \\
\hline Harpacticoid copepods & 1.9 & 1.9 & 1.9 & 1.9 & 1.9 & 0.0 & 5.6 & 7.5 \\
\hline Nauplii & 0.0 & 0.0 & 0.0 & 0.0 & 0.0 & 1.9 & 1.9 & 1.9 \\
\hline Mites & 1.9 & 0.0 & 3.8 & 0.0 & 1.9 & 0.0 & 0.0 & 3.8 \\
\hline Bivalves & 0.0 & 0.0 & 0.0 & 0.0 & 3.8 & 0.0 & 1.9 & 1.9 \\
\hline Polychaetes & 0.0 & 0.0 & 1.9 & 0.0 & 0.0 & 5.6 & 3.8 & 1.9 \\
\hline Gastrotrichs & 1.9 & 0.0 & 0.0 & 0.0 & 0.0 & 0.0 & 0.0 & 0.0 \\
\hline Total & 90.2 & 65.8 & 58.3 & 45.1 & 466.2 & 229.4 & 511.4 & 342.2 \\
\hline \multicolumn{9}{|l|}{ Biomass ( $\mu \mathrm{gDW} 10 \mathrm{~cm}^{-2}$ ) } \\
\hline Nematodes & 4.76 & 1.55 & 0.98 & 2.26 & 14.13 & 9.90 & 20.71 & 15.51 \\
\hline Harpacticoid copepods & 0.10 & 0.74 & 11.52 & 2.98 & 2.98 & 0.00 & 11.31 & 13.83 \\
\hline Nauplii & 0.00 & 0.00 & 0.00 & 0.00 & 0.00 & 0.04 & 0.16 & 0.05 \\
\hline Mites & 1.02 & 0.00 & 0.00 & 2.10 & 0.48 & 0.00 & 0.00 & 0.77 \\
\hline Bivalves & 0.00 & 0.00 & 0.00 & 0.00 & 4976.83 & 0.00 & 716.87 & 64.35 \\
\hline Polychaetes & 0.00 & 0.00 & 9.25 & 0.00 & 0.00 & 61.08 & 2.96 & 0.43 \\
\hline Gastrotrichs & 0.05 & 0.00 & 0.00 & 0.00 & 0.00 & 0.00 & 0.00 & 0.00 \\
\hline Total & 5.93 & 2.29 & 21.75 & 7.34 & 4994.43 & 71.02 & 752.02 & 94.94 \\
\hline
\end{tabular}
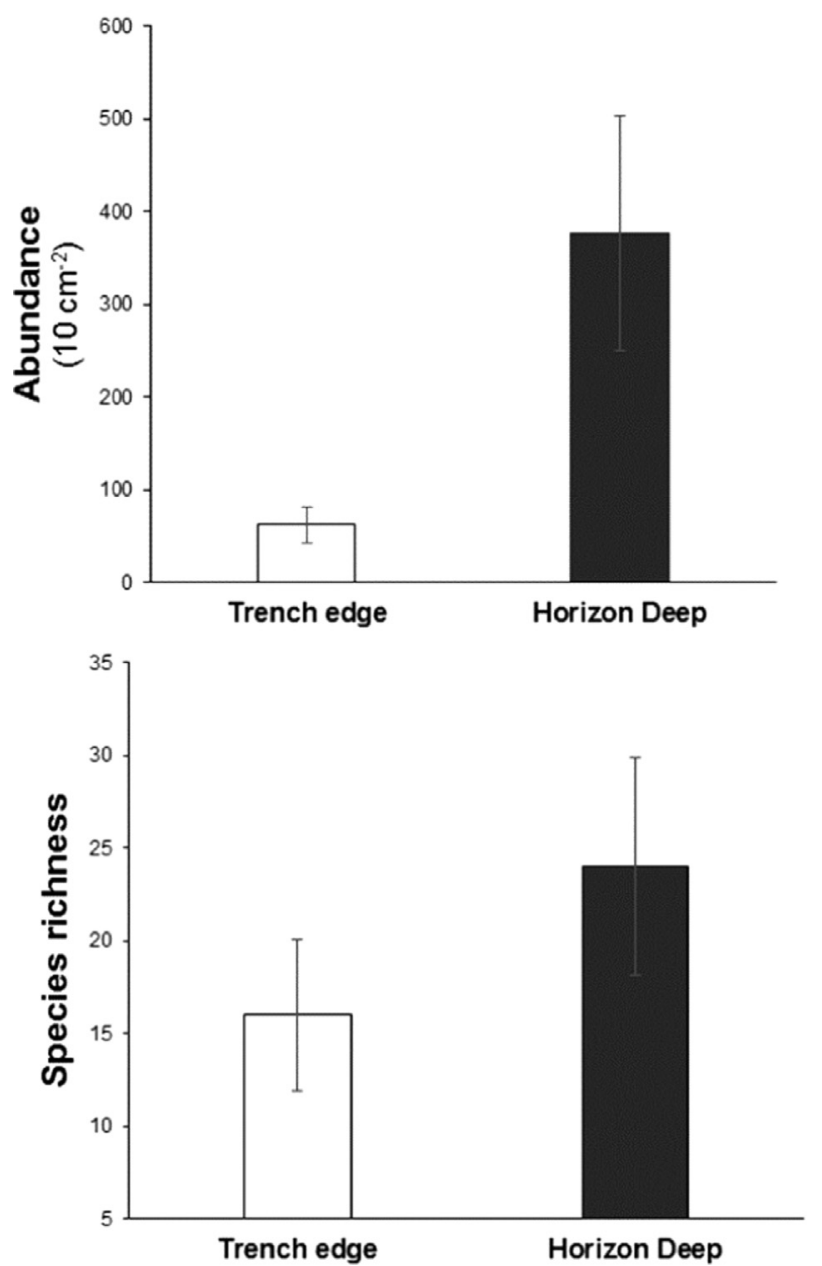
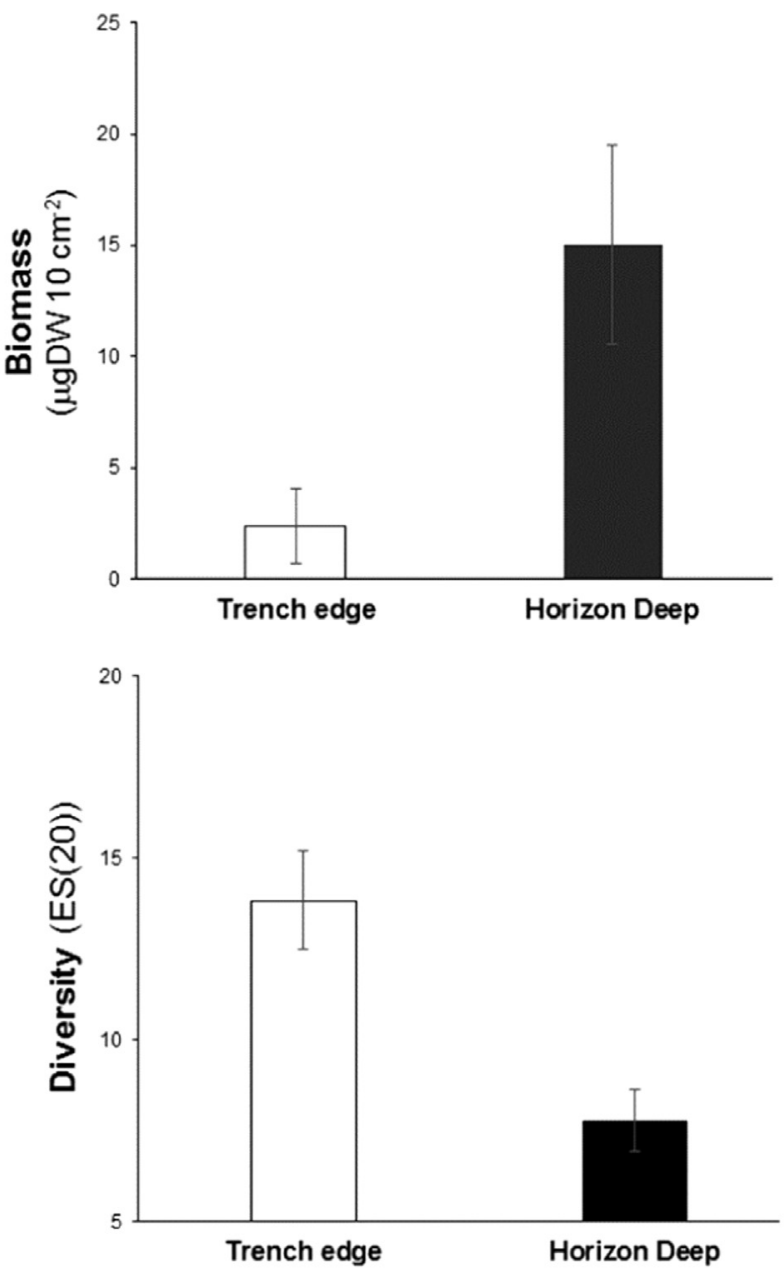

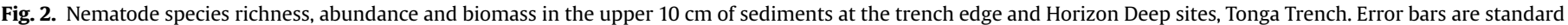
deviations from the mean $(N=4)$. 


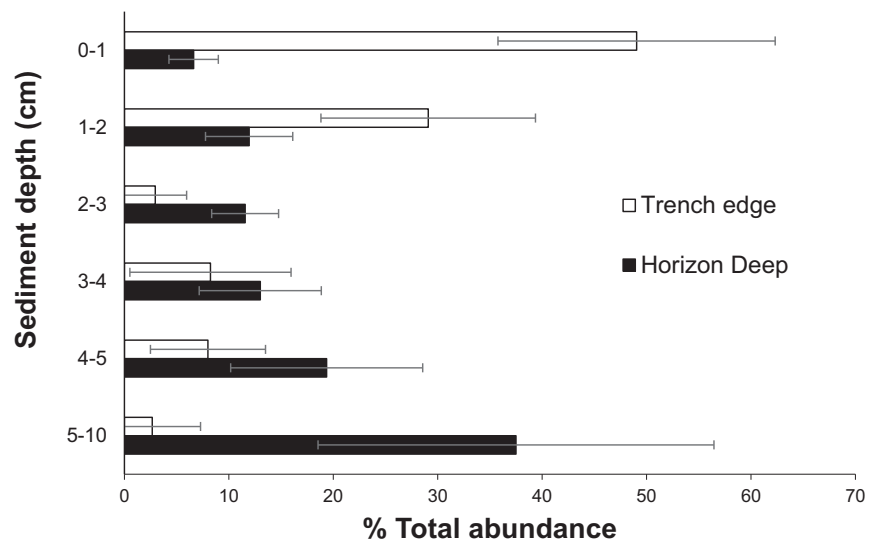

Fig. 3. Mean abundance of nematodes, expressed as percentage of total depthintegrated abundance, at different sediment depths (trench edge and Horizon Deep sites, Tonga Trench). Error bars are standard deviations from the mean $(N=4)$.

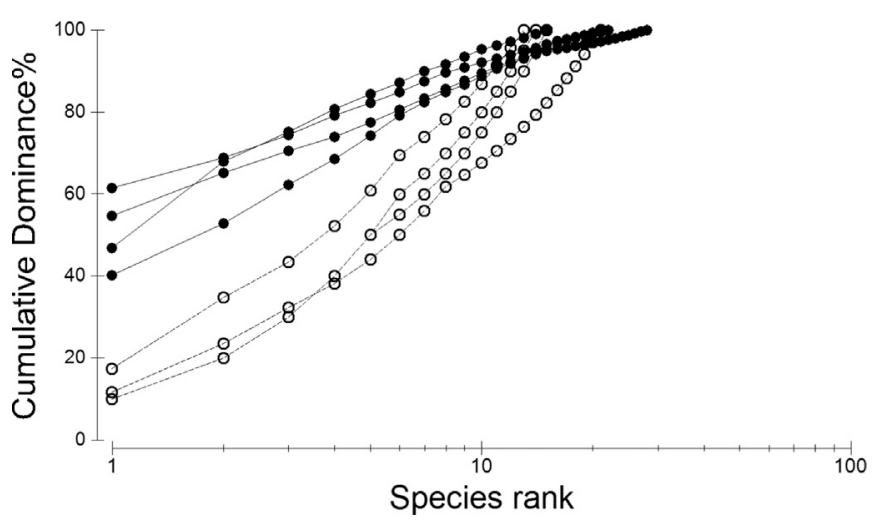

Fig. 4. Nematode species dominance plots of trench edge (empty circles) and Horizon Deep samples (filled circles).

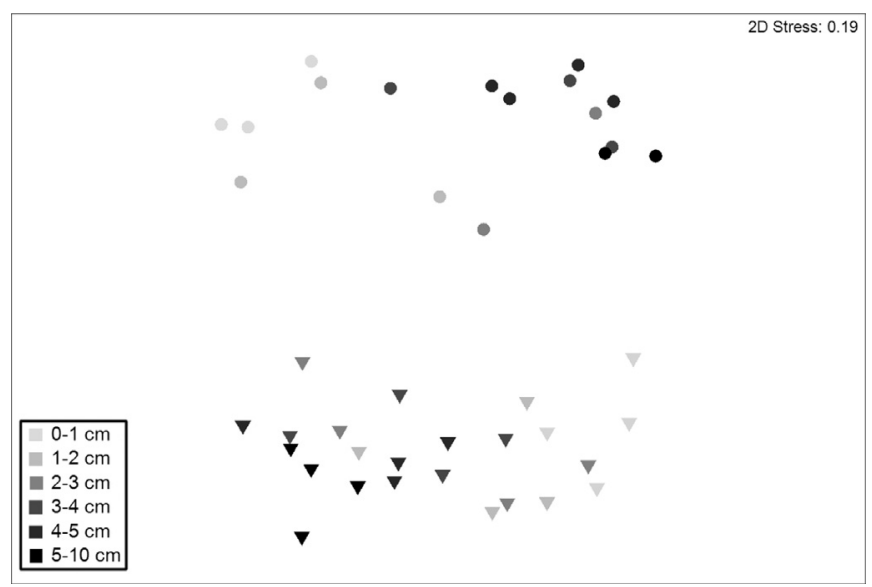

Fig. 5. Two dimensional MDS configuration for nematode species abundance at different sediment depths $(0-1,1-2,2-3,3-4,4-5$, and 5-10 cm layers; light grey to black symbols) at the Horizon Deep (triangles) and trench edge study site (circles).

subsurface sediments, whereas at the Horizon Deep site Manganonema kitasatoi dominated surface sediments and became less abundant in deeper layers where Monhystrella sp. B and Lamyronema horizonensis dominated.

\subsection{Sediment environment}

Sediment grain size characteristics were similar at the two study sites, and consisted mostly of silt particles (90-94\%, Table 4). Sediment mean grain size, sorting, and particle size diversity were all
Table 2

Results of PERMANOVA analysis testing for the effects of site (trench edge vs Horizon Deep), sediment depth $(0-1,1-2,2-3,3-4,4-5$ and 5-10 cm) and their interaction on nematode species community structure. $\mathrm{DF}=$ degrees of freedom; $\mathrm{SS}=$ sum of squares; $\mathrm{MS}=$ mean sum of squares, Perms = number of unique permutations; $\sqrt{ } \mathrm{ECV}=$ square root of estimates of components of variation.

\begin{tabular}{lrrrlllll}
\hline & DF & SS & MS & Pseudo-F & $\boldsymbol{P}$ & Perms & $\sqrt{ }$ ECV \\
\hline Site & 1 & 25,282 & 25282 & 9.715 & 0.032 & 751 & 36.6 \\
Sediment depth & 5 & 15,318 & 3063.7 & 2.161 & 0.001 & 998 & 16.3 \\
Core (Site) & 6 & 16,642 & 2773.6 & 1.956 & 0.001 & 998 & 16.7 \\
$\begin{array}{l}\text { Site } \times \text { Sediment } \\
\quad \text { depth }\end{array}$ & 5 & 16,987 & 3397.5 & 2.396 & 0.001 & 996 & 25.3 \\
$\begin{array}{l}\text { Residuals } \\
\text { Total }\end{array}$ & 23 & 32,607 & 1417.7 & & & & 37.7 \\
\hline
\end{tabular}

Table 3

SIMPER results showing nematode species responsible for within-group similarity at the trench edge and Horizon Deep sites (0-10 cm sediment depth). Av. Abund.= average abundance in sample; $\mathrm{Sim} / \mathrm{SD}=$ similarity/standard deviation; Contrib\%= contribution to overall similarity; Cum\%=cumulative similarity; Av. sim.=average similarity.

\begin{tabular}{|c|c|c|c|c|c|}
\hline & Av.Abund & Av.Sim & $\operatorname{Sim} / S D$ & Contrib\% & Cum.\% \\
\hline \multicolumn{6}{|l|}{$\begin{array}{l}\text { Trench edge (Av. } \\
\text { sim. }=50.2 \%)\end{array}$} \\
\hline Monhystrella_E & 3.0 & 8.0 & 7.1 & 16.0 & 16.0 \\
\hline Monhystrella_A & 2.8 & 7.8 & 8.6 & 15.5 & 31.5 \\
\hline Manganonema_E & 1.5 & 5.8 & 3.9 & 11.5 & 42.9 \\
\hline Aegialoalaimus_A & 1.0 & 5.3 & 7.6 & 10.6 & 53.6 \\
\hline Desmolorenzenia_A & 1.3 & 5.3 & 7.6 & 10.6 & 64.2 \\
\hline Diplopeltoides_A & 1.3 & 3.4 & 0.9 & 6.8 & 71.0 \\
\hline Acantholaimus_C & 1.8 & 2.9 & 0.9 & 5.7 & 76.7 \\
\hline Microlaimus_A & 1.3 & 2.9 & 0.9 & 5.7 & 82.4 \\
\hline Campylaimus_A & 1.0 & 2.6 & 0.9 & 5.1 & 87.5 \\
\hline Cyatholaimidae_A & 0.8 & 0.8 & 0.4 & 1.6 & 89.1 \\
\hline Manganonema_B & 0.8 & 0.8 & 0.4 & 1.6 & 90.7 \\
\hline \multicolumn{6}{|l|}{$\begin{array}{l}\text { Horizon Deep (Av. } \\
\quad \text { sim. }=66.0 \%)\end{array}$} \\
\hline Monhystrella_B & 99.5 & 17.3 & 7.4 & 26.2 & 26.2 \\
\hline Manganonema_kitasatoi & 19.3 & 7.8 & 2.9 & 11.8 & 38.0 \\
\hline Monhystrella_A & 9.8 & 5.3 & 6.3 & 8.1 & 46.1 \\
\hline Lamyronema horizonensis & 10.0 & 5.2 & 4.2 & 7.9 & 53.9 \\
\hline Desmoscolex_A & 6.5 & 5.0 & 6.9 & 7.6 & 61.5 \\
\hline Daptonema amphorum & 4.0 & 3.4 & 5.2 & 5.1 & 66.6 \\
\hline Ceramonematidae_A & 4.5 & 3.0 & 2.6 & 4.5 & 71.2 \\
\hline Monhystrella_C & 3.0 & 2.6 & 7.0 & 4.0 & 75.2 \\
\hline Metadesmolaimus_B & 1.8 & 2.6 & 3.3 & 4.0 & 79.1 \\
\hline Manganonema_B & 7.5 & 2.3 & 0.9 & 3.4 & 82.5 \\
\hline Monhystrella_E & 1.5 & 2.1 & 7.2 & 3.2 & 85.8 \\
\hline Greeffiella_A & 2.5 & 1.7 & 0.9 & 2.5 & 88.3 \\
\hline Halalaimus_A & 1.5 & 1.6 & 0.9 & 2.4 & 90.6 \\
\hline
\end{tabular}

Table 4

Sediment grain size parameters at the trench edge and Horizon Deep study sites.

\begin{tabular}{|c|c|c|c|c|}
\hline & \multicolumn{2}{|c|}{ Trench edge } & \multicolumn{2}{|c|}{ Horizon deep } \\
\hline & Core 4 & Core 9 & $10811 \mathrm{~m}$ & $10817 \mathrm{~m}$ \\
\hline Mean grain size ( $\mu \mathrm{m}$, geometric) & 10.33 & 10.11 & 8.72 & 9.93 \\
\hline Particle sorting & 3.07 & 2.98 & 2.60 & 2.70 \\
\hline$\%$ Sand & 7.01 & 5.98 & 2.51 & 4.06 \\
\hline$\%$ Silt & 90.14 & 90.83 & 94.29 & 93.59 \\
\hline \%Clay & 2.84 & 3.20 & 3.20 & 2.34 \\
\hline Particle size diversity & 0.81 & 0.80 & 0.75 & 0.77 \\
\hline
\end{tabular}

slightly lower at the Horizon Deep site than at the trench edge site, however no statistical tests could be conducted due to the low number of samples $(N=2)$. 

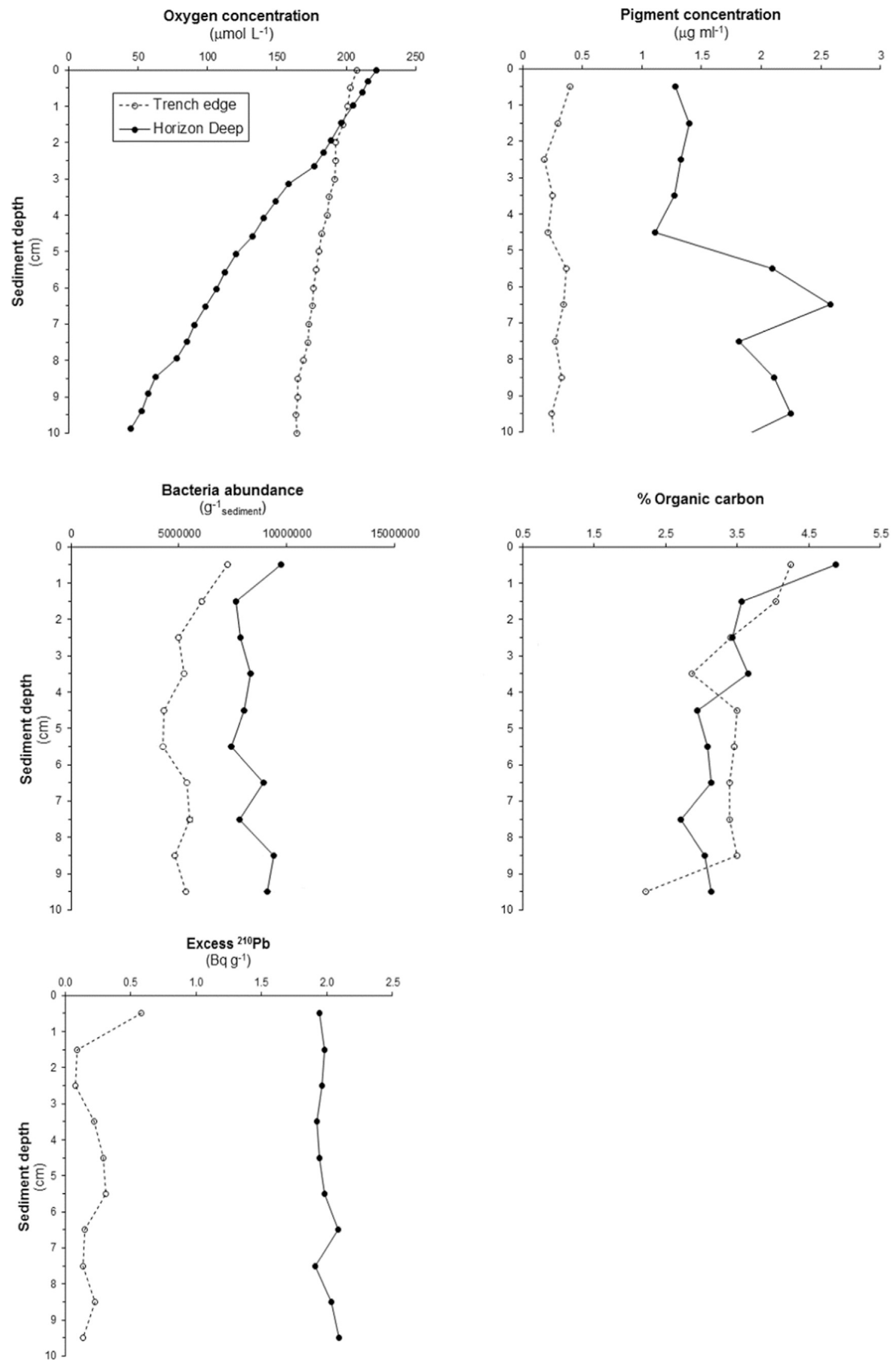

Fig. 6. Examples of sediment parameter profiles at the trench edge and Horizon Deep study sites (\% organic carbon based on wet weight). Full datasets are presented in Wenzhoefer et al. (this issue). 


\section{Discussion}

Comparison of infaunal communities at the Horizon Deep and trench edge sites in the Tonga Trench revealed marked contrasts in almost all of the community attributes we investigated, and provided support for our hypothesis regarding contrasts in abundance, biomass, and community structure between the sites. Patterns of species richness and diversity, however, were not consistent due to differences in nematode abundance and degree of dominance between the sites. The presence of contrasting patterns in the vertical distribution of infauna in the sediments between the two study sites supported our additional hypothesis. In the following discussion, we compare our results to published data, and highlight potential relationships with food availability. The patterns in meiofauna abundance are compared and discussed in relation to in situ benthic measurements of $\mathrm{O}_{2}$ distribution and biogeochemical data obtained in a parallel study (Wenzhoefer et al., this issue). We also consider other ecological processes that may be driving differences in community attributes between the two study sites.

\subsection{Abundance and biomass}

Data on infaunal abundance at $>6000 \mathrm{~m}$ depths are available from Puerto Rico Trench (George and Higgins, 1979; Tietjen, 1989; Tietjen et al., 1989; Richardson et al., 1995), Aleutian Trench (Jumar \& Hessler 1976), Kuril and Ryuku trenches (Itoh et al., 2011; Kitahashi et al., 2013), Japan Trench (Shirayama and Kojima, 1994), Ogasawara Trench (Shirayama, 1984a), Peru-Chile Trench (Danovaro et al., 2002) and South Sandwich Trench (Vanhove et al., 2004), with the deepest quantitative sample obtained at $8386 \mathrm{~m}$ in Puerto Rico Trench (Tietjen, 1989). The Horizon Deep samples obtained in the present study represent the deepest quantitative samples of benthic infauna to date, and comparisons with published data shows that infaunal abundances at this location (229511 ind. $10 \mathrm{~cm}^{-2}$ ) were either comparable or higher than meiofaunal values from other trenches at $6380-8380 \mathrm{~m}$ depths (mean $=44-754$ ind $10 \mathrm{~cm}^{-2}$ ), with the exception of the PeruChile Trench, where meiofaunal abundance was exceptionally high at $7800 \mathrm{~m}$ (mean $=6378$ ind. $10 \mathrm{~cm}^{-2}$; Danovaro et al., 2002). Infaunal abundance in samples from the edge of Tonga Trench at $6250 \mathrm{~m} \mathrm{(45-90} \mathrm{ind.} 10 \mathrm{~cm}^{-2}$ ) were among the lowest reported for trench and abyssal plain environments below $5000 \mathrm{~m}$ depth listed in Danovaro et al. (2002) and Schmidt and Martinez-Arbizu (2015). Similar mean densities of $<100$ ind. $10 \mathrm{~cm}^{-2}$ were reported in Puerto Rico Trench at 7460-8376 m (Tietjen et al., 1989; Richardson et al., 1995) and Ogasawara Trench at 5730 and $5820 \mathrm{~m}$ (Shirayama, 1984a).

The relatively high and variable biomass values at the Horizon Deep site (71-4994 $\mu \mathrm{gDW} 10 \mathrm{~cm}^{-2}$ ) were mainly due to the presence of bivalves in three of the samples. When these bivalves, which are not normally considered as belonging to the meiofauna, are excluded, biomass values become comparable to meiofaunal values from most other trenches where data are available at depths below $6000 \mathrm{~m}$ (18-71 vs 4-68 $\mu \mathrm{gDW} 10 \mathrm{~cm}^{-2}$; Shirayama, 1984a; Tietjen, 1989; Shirayama and Kojima, 1994). However these values are about one and two orders of magnitude lower than meiofauna biomass in the Kuril (7000 m depth) and Peru-Chile trenches $(7800 \mathrm{~m})$, respectively (Danovaro et al., 2002; Itoh et al., 2011). This difference in meiofaunal biomass is consistent with contrasts in estimated particulate organic matter flux to the seafloor, with values approximately three times greater at the Kuril and Peru-Chile trenches relative to Tonga Trench (Jamieson, 2015).

The higher abundance and biomass of infauna at the Horizon Deep site relative to the trench edge site is consistent with independent biogeochemical data obtained from cores obtained in a parallel study (Wenzhoefer et al., xxx). Vertical gradients in oxygen concentrations at the Horizon Deep site showed faster attenuation with sediment depth than at the trench edge site (Fig. 6), and the average oxygen consumption calculated form these profiles was two times greater in the former (mean and standard deviation: $225 \pm 50 \mu \mathrm{mol} \mathrm{m}^{-2} \mathrm{~d}^{-1}$ ) relative to the latter $\left(92 \pm 44 \mu \mathrm{mol} \mathrm{m}{ }^{-2} \mathrm{~d}^{-1}\right)$ (Wenzhoefer et al., this issue). Horizon Deep sediments were also enriched with respect to bacteria abundance and pigment concentrations relative to trench edge sediments; organic carbon content at the two sites, however, was similar (Fig. 6). Taken together, these data suggest that whilst the total organic matter concentrations may be similar at the Horizon Deep and trench edge sites, deposition of more labile and perhaps fresher phytodetritus (available food) at the deepest site is responsible for elevated benthic metabolism and abundance and biomass of infauna at the former site.

A marked difference in meiofaunal abundance was observed in samples from the deep Peru-Chile Trench floor and adjacent continental slope (Danovaro et al., 2002), with mean abundance ten times greater on the slope than in the trench. Meiofaunal biomass, however, was about the same in the two environments. This lack of difference in biomass likely reflects similar availability of food in trench and slope sediments, as indicated by comparable pigment, protein, lipids, and organic matter concentrations (Danovaro et al., 2002). Interestingly, the abundance and biomass of bacteria was lower at the deep Peru-Chile Trench floor than on the slope (Danovaro et al., 2008), which is the reverse of what was observed in the Mariana Trench (Glud et al., 2013) and the Tonga Trench. Therefore, whilst the latter study shows that meiofaunal abundance is exceptionally high in the Peru-Chile Trench, it does not provide evidence for organic matter accumulation/concentration or infaunal biomass above levels recorded in nearby shallower habitats of the region. A similar lack of bathymetric trend in food availability was observed between the continental slope and the Japan, Kuril and Ryukyo trenches (7000-7500 m depth), where meiofaunal biomass values showed little variation below 2000 m depth (Shirayama and Kojima, 1994; Itoh et al., 2011).

At trenches where the productivity of the overlying water is less than at the Peru-Chile Trench and trenches off Japan (Jamieson, 2015), patterns differ. Data from the Ogasawara Trench show no pattern in meiofaunal abundance between 4000 and $8000 \mathrm{~m}$ (Shirayama, 1984a), whilst a decreasing trend in meiofaunal abundance was observed in the Ryuku Trench (Itoh et al., 2011). In Puerto Rico Trench, particulate organic carbon flux to the seafloor and bacterial abundance was lower at the deepest $(8189 \mathrm{~m})$ trench site relative to shallower trench and abyssal plain sites, and meiofaunal biomass was highest on the abyssal plain (Tietjen et al., 1989). Most recently, Glud et al. (2013) provided evidence for intensified microbial metabolism at the Challenger Deep in the Mariana Trench relative to its trench edge. However, macro-infauna was not investigated in core samples from either environments. Whether the elevated metabolism was associated with higher meiofaunal abundance and biomass remains unknown.

Food availability at the seafloor in trenches is not solely dependent upon the productivity of the overlying water, but is thought to also be influenced by the extent of the topographicallydriven concentration of organic matter (Ichino et al., 2015). Thus, when comparing community data from different trenches, or even within trenches, it is important to consider the distinct topographies that characterise the continental slope (or fore-arc), and oceanic slope. In the studies of Danovaro et al. (2002) and Itoh et al. (2011) at the high surface water productivity Peru-Chile and Kuril/Ryukyu trenches, the study sites that show little or no difference in benthic biomass or food availability are primarily or exclusively located on the fore-arc where the continental shelf and the deepest parts of the trench are separated by a relatively even 
and steep-angled slope over relatively short (100-200 km) distances. When sampled, abyssal sites located on the oceanic slope on the other side of the trench are on a more shallow-angled slope and are characterised by low food availability relative to the trench floor (Itoh et al., 2011). The study of Glud et al. (2013) and the present study that compare sites at the deep trench floor adjacent to the steep sides of the trench and shallower sites situated on the low-angled oceanic slope show elevated microbial activity/faunal abundance and biomass at the former sites. However, the comparisons of meiofauna abundance and biomass between two sites in the Puerto Rico Trench and an abyssal site on the oceanic slope by Tietjen et al. (1989) showed the opposite pattern, which may have resulted from the relatively long distances between the abyssal plain and trench sites $(\sim 1500 \mathrm{~km})$ and relative proximity of the abyssal plain site to the mainland. Thus, whether the deep trench floor is characterised by elevated infauna abundance and biomass relative to shallower environments may depend not only on the productivity of the overlying water (i.e. the potential vertical flux of organic matter) and the extent of the topographic concentration (or lateral flux) of organic matter resulting from the relative angles of the oceanic or continental slope, but potentially other factors such as distance to land (the source of terrestrial or coastal organic matter). The particular location of study sites within a trench is also likely to be important given the highly complex topography of trenches. More detailed investigations may find that different bathymetric trends in faunal abundance and biomass are present in different parts of a trench, as predicted by the recent hadal organic matter transport model of Ichino et al. (2015).

\subsection{Contribution of infauna to benthic oxygen consumption}

Infaunal respiration, and their contribution to total benthic oxygen consumption, can be estimated based on the allometric equation of Mahaut et al. (1995) relating respiration rate to individual dry weight (Baguley et al., 2008). Estimates based on this method (which exclude the disproportionate contributions of four large bivalves in the Horizon Deep samples) suggest that mean infaunal oxygen consumption was four times greater at the Horizon Deep site than at the trench edge site (55.6 vs $12.8 \mu$ mol m $\mathrm{m}^{-2} \mathrm{~d}^{-1}$, respectively), and accounted for an average of 19 and $8 \%$ of total sediment oxygen consumption, respectively (see Wenzhofer et al. (this issue) for details on total sediment oxygen consumption at the study sites). These estimates indicate that the contribution of infauna to benthic metabolism at the Tonga Trench study sites is of similar magnitude to the contribution of meiofauna to benthic metabolism of continental slope and abyssal plain habitats ( 4-50\%; Piepenburg et al., 1995; Heip et al., 2001; Rowe et al., 2008). The contribution of infauna to benthic metabolism, particularly at the Horizon Deep site, is substantial, suggesting an important role of infauna in the mineralisation of organic matter reaching the trench floor.

\subsection{Vertical distribution in the sediments}

The vertical distribution of nematodes at the trench edge site, where most individuals were concentrated in top few centimetres of sediment, was similar to the type of distribution commonly observed in trench and other deep-sea environments (Shirayama, 1984b; Tietjen et al., 1989; Itoh et al., 2011). The high density of nematodes in the deepest $(5-10 \mathrm{~cm})$ sediment layer at the Horizon Deep site, however, is unusual and has not been observed previously in any deep-sea habitat. Oxygen penetration depth exceeded the depth of infaunal cores (Fig. 6), and this factor is therefore unlikely to have limited the penetration of nematodes into the sediments. The distribution of phytopigments and bacteria, however, differed between the two sites. At the Horizon Deep site, phytopigment concentration was highest below five centimetres depth and bacterial abundance was constant at all depths; at the trench edge site, phytopigment concentration showed little variation with depth whilst bacteria abundance was highest in the surface layer (Fig. 6). It seems likely that the unusual vertical distribution of nematodes at Horizon Deep reflects the subsurface peak in food availability at this location. In the Puerto Rico Trench, Tietjen et al. (1989) found a positive correlation between bacterial and meiofaunal densities, which in that trench both decreased with depth. They also observed a higher abundance of meiofauna and bacteria in subsurface sediments of a site characterised by elevated bioturbation. $\mathrm{Pb}_{210}$ profiles from the Horizon Deep site are consistent with well-mixed sediments beyond $10 \mathrm{~cm}$ below the sediment surface (Fig. 6). Physical disturbance through settlement of sediment and organic matter from shallower depths through gravity and turbidite flows (Balance, 1991; Oguri et al., 2013; Nomaki et al., in press) is the most likely mechanism behind the lack of gradient in the Horizon Deep $\mathrm{Pb}_{210}$ profile an high absolute values of excess $\mathrm{Pb}_{210}$ (Ikehara et al., 2014). Observations of amphipod behaviour from video recordings at the Tonga Trench study sites indicate that mobile scavenging amphipods seeking refuge in the sediment may contribute to sediment mixing. Higher abundance of large scavenging amphipods from baited trap samples at the Horizon Deep site relative to the trench edge site also suggest that this bioturbation potential is greater in the former than in the latter (A. Rowden unpublished data). Bioturbation by the relatively large bivalves and polychaetes abundant at the Horizon Deep site could also help explain why phytopigments, bacteria, and nematodes occur deeper in the sediment at this site compared to the trench edge. Most of the fauna in the $5-10 \mathrm{~cm}$ sediment layer were small bacterial feeding nematodes of the genus Monhystrella. This genus belongs to a family of nematodes also common in coastal environments and categorised as colonisers by Bongers (1990) due to their short lifecycle, high colonisation ability, and tolerance to disturbance, eutrophication and hypoxia. Their high abundance deep in the sediments of Horizon Deep site is consistent with disturbed (or reworked) sediments with abundant bacterial food resources.

\subsection{Species diversity}

Food availability is thought to be a major driver of diversity in the deep sea, and has often been invoked to explain diversity trends in hadal trench studies (Tietjen, 1989; Gambi et al., 2003; Fujii et al., 2013). Here, we observed no difference in species richness between the Horizon Deep and trench edge sites but observed higher diversity measured using Hulbert's (1971) rarefaction method [ES(20)] at the trench edge site. The results on nematode species richness in the Tonga Trench contrasted with the usually low species richness observed at the hadal trench floors relative to shallower environments. Studies of hadal nematodes by Tietjen (1989) and Gambi et al. (2003) showed substantially lower nematode species richness at the deep trench floor relative to abyssal plain and continental slope sites. The results of Gambi et al. (2003) on hadal species richness, however, are based on the identification of a subsample of only 275 nematodes (or about $2 \%$ of all nematodes present in the three hadal cores that they processed) and their estimates of species richness should therefore be viewed with caution. Kitahashi et al. (2013) observed a similar overall bathymetric trend to Gambi et al. (2003) in harpacticoid genus diversity, but patterns differed somewhat depending on whether genus richness or expected genus richness based on rarefaction were used as the metric of diversity. While both metrics showed a decrease in diversity from their respective bathyal or abyssal depth maxima to the deepest part of the trench, 
this trend was weak (Kitahashi et al., 2013). Our results also show that bathymetric patterns are not necessarily consistent depending on which of these two types of diversity metric is used.

Physical characteristics of sediments have also been linked with the diversity of infauna. Some studies have shown a positive correlation between sediment grain size diversity (a measure of habitat heterogeneity) and the diversity of deep-sea macro- and meiofauna (Etter and Grassle, 1992; Leduc et al., 2012). A study by Kitahashi et al. (2013), which included sites from bathyal to hadal depths, showed a correlation between sediment particle sorting (another measure of habitat heterogeneity) and harpacticoid copepod diversity. However, in their study the nature of the relationship, positive or negative with increased sorting (or habitat heterogeneity), depended on which of two metrics they employed to quantify diversity. Nonetheless, the difference in sorting and diversity between hadal and abyssal sites was minimal. In the Tonga Trench there was only limited differences in both species richness and sediment grain size parameters between the two study sites, with Horizon Deep sediments characterised by slightly lower particle size diversity than at the trench edge site. The lack of variation in nematode species richness at the study sites may therefore be a reflection of the similar physical characteristics of the sediment.

The nematode community at the Horizon Deep site was dominated by a few abundant species. A pattern of increased dominance of a small number of species in the deepest parts of hadal trenches is common (e.g. Gambi et al., 2003), and is thought to be related to the limited number of species able to thrive at great depths (Belyaev, 1972). It is also possible that abundant food resources lead to increased rates of competitive exclusion (Rex, 1983), and high dominance of a few opportunistic taxa such as Monhystrella at the Horizon Deep site.

There has been some confusion related to the identification of the small and morphologically similar genera Monhystrella and Thalassomonhystera (Fonseca et al., 2008). Vanhove et al. (2004) and Gambi et al. (2003) recorded high densities of the similar genus Monhystera in hadal trench habitats, but a taxonomic revision by Jacobs (1987) almost two decades earlier resulted in all marine Monhystera species being transferred to either Thalassomonhystera or Monhystrella (Fonseca and Decraemer, 2008). It is therefore unclear which of these genera was recorded by previous trench studies and the two are therefore referred to as "Monhysteridae" below for literature comparison purposes.

The family Monhysteridae and genus Manganonema were dominant at both the Tonga Trench study sites, although each site was dominated by different species. The Monhysteridae are an opportunistic and competitive taxon common in most deep-sea habitats including hadal trenches, abyssal plain, continental slopes, hydrothermal vents, and seeps (Vanreusel et al., 2010). This taxon represented about one quarter of total nematodes in the Peru-Chile $(7800 \mathrm{~m})$ and South Sandwich trenches $(6300 \mathrm{~m})$ (Gambi et al., 2003; Vanhove et al., 2004), but was not present in the Puerto-Rico Trench (Tietjen, 1989). Monhysteridae were comparatively highly dominant in Horizon Deep and comprised $60 \%$ of all nematodes. In contrast to the Monhysteridae, the exclusively deep-sea genus Manganonema is typically found at low densities and is never dominant. It was recorded in the South Sandwich Trench $(\sim 1 \%$ of total nematode abundance, Vanhove et al., 2004), but not the PeruChile Trench; Manganonema was originally described in 1993 after the study of Tietjen (1989) on Puerto Rico Trench, and its presence there cannot be ascertained. Nevertheless, the high densities of Manganonema at the trench edge and Horizon Deep study sites (7\% and $15 \%$, respectively) are unusually high. Tonga Trench is characterised by some unusually large species of Manganonema (twice the size of all other species), suggestive of a favourable environment for this genus (Leduc, 2015).

\subsection{Community structure}

High levels of community dissimilarity between the fauna of the trench floor and abyssal plains have been reported $(81 \%$, Kitahashi et al., 2013; 87\%, Gallo et al., 2015). There have been similar levels recorded between the trench floor and the trench edge/ slope immediately beyond the trench (76.4\%, Fujii et al., 2013; 76\%, Kitahashi et al., 2013). In the Tonga Trench, infaunal community dissimilarity between the deep trench floor at the Horizon Deep site and trench edge site was $82.4 \%$, and only a quarter of species were found at both sites. Taken together, the results of the present and previous studies suggest that benthic communities outside and at the edge of the trench are very different from those within the trench itself, especially the deep trench floor. More specifically, the results of the present study and previous studies indicate that faunal communities at depths not much greater than $6000 \mathrm{~m}$ (6253 m, present study; $6007 \mathrm{~m}$, Jamieson et al., 2011; $6173 \mathrm{~m}$, Fujii et al., 2013) are different from those in the trench, even though both are at hadal depths. However, the hadal zone has also been defined as beginning at $6500 \mathrm{~m}$ (Watling et al., 2013), which these studies suggest may be a more appropriate depth horizon, and could be associated with both a hydrostatic pressure-related influence on the bathymetric distribution of life as well as an ecological one associated with the peculiarities of the trench environment itself.

Fujii et al. (2013) reported 52\% similarity between scavenging amphipod communities at the edge of the Kermadec Trench $(6000 \mathrm{~m})$ and $73 \%$ at depths of $7000-8000 \mathrm{~m}$ within the trench. In the Tonga Trench, nematode community similarity showed a comparable difference, with 50 vs $66 \%$ similarity at the trench edge and Horizon Deep sites, respectively. Levels of similarity, or multivariate dispersion (which follow the same pattern in the present study), are indicative of environmental heterogeneity (Anderson et al., 2006), and have previously been used to infer the influence of substratum heterogeneity on megafauna community structure at abyssal compared to hadal habitats in the New Britain Trench (Gallo et al., 2015). The results from the Tonga Trench suggest a relatively homogeneous distribution of species over the $\sim 300 \mathrm{~m}$ distance separating the two deployments of the deep-sea camera system in Horizon Deep. This homogeneity in community structure could be the result of large scale disturbance event (s) such as gravity/turbidite flows affecting the wider area, or through intense bioturbation of sediments destroying horizontal habitat heterogeneity. The greater patchiness in community structure at the trench edge site was largely due to a single core, which was taken $<30 \mathrm{~m}$ away from the other three cores, thereby suggesting a patchy distribution of nematodes at this scale. This patchy distribution is unlikely to result from substratum variability because no substantial difference in particle size distribution was observed between the two cores from this site.

\section{Conclusions}

Hadal trenches are topographically complex habitats characterised by benthic communities distinct from those of shallower environments. Whilst it is not yet possible to determine the relative influences of different environmental factors on hadal trench benthic communities, results from the present study in Tonga Trench add to other studies suggesting that food availability is likely to be a key driver. Food availability is also likely to have a strong influence on bioturbation rates (Smith, 1992), which in turn, may shape communities of meiofaunal organisms. The present study suggests that physical disturbance from turbidite may influence the vertical distribution of food, bacteria, and smaller fauna in deep trench environments. The effects of physical 
disturbance may be particularly pronounced in trenches due to the fine and unconsolidated nature of the sediments.

Hadal trenches are characterised by environmental conditions not found in any other deep-sea environment, thereby providing new opportunities to understand the processes that shape benthic communities. The characterisation of bathymetric trends in benthic community abundance and diversity, for example, have been mostly restricted to bathyal and abyssal depths, and thus only cover the upper half of the full ocean depth range. As more studies include hadal environments these may provide new insights into the factors shaping large-scale patterns of benthic communities in the deep sea and modify existing ecological paradigms. Studies of hadal trenches should also include multiple sample stations from oceanic and continental slopes to better reflect the wide range of topographies and environments present in individual trenches, and better characterise transitions between hadal, abyssal, and slope communities.

\section{Acknowledgements}

Funding was provided by NIWA's Coasts and Oceans Centre Research Programme 2 (2013/14 SCI) and by the New Zealand Ministry of Business, Innovation and Employment (MBIE) through NIWA's research programme 'Impact of resource use on vulnerable deep-sea communities' (CO1 $\times 0906)$. The study was also supported by JAMSTEC, the Natural Environment Research Council (NERC, NE/F018612/ 1; NE/F0122991/1, NE/G006415/1), ERC through two Advanced Grants (ERC-2010-AdG20100224), the Max Planck Society, and the Danish Council for Independent Research (FNU-09-072829). At NIWA, we are grateful to Lisa Northcote for the sediment grain size analyses, Kevin Mckay for constructing Fig. 1, and Scott Nodder for his generous support. We would also like to thank the officers, crew and scientific personnel of $R V$ Yokosuka voyage YK13-10. We thank three anonymous reviewers for their constructive criticisms on the manuscript.

\section{Appendix A. Supplementary material}

Supplementary data associated with this article can be found in the online version at http://dx.doi.org/10.1016/j.dsr.2015.11.003.

\section{References}

Alongi, D.M., 1992. Bathymetric patterns in deep-sea benthic communities from bathyal to abyssal depths in the western South Pacific (Solomon and Coral Seas). Deep-Sea Res. 39, 549-565.

Anderson, M.J., Ellingsen, K.E., McArdle, B.H., 2006. Multivariate dispersion as a measure of beta diversity. Ecol. Lett. 9, 683-693.

Anderson, M.J., Gorley, R.N., Clarke, K.R., 2008. PERMANOVA+ for PRIMER: Guide to Software and Statistical Methods. PRIMER-E, Plymouth.

Anderson, M.J., Crist, T.O., Chase, J.M., Vellend, M., Inouye, B.D., Freestone, A.L., Sanders, N.J., Cornell, H.V., Comita, L.S., Davies, K.F., Harrison, S.P., Kraft, N.J.B., Stegen, J.C., Swenson, N.G., 2011. Navigating the multiple meanings of $\beta$ diversity: a road map for the practicing ecologist. Ecol. Lett. 14, 19-28.

Baguley, J.G., Montagna, P.A., Hyde, L.J., Rowe, G.T., 2008. Metazoan meiofauna biomass, grazing, and weight-dependent respiration in the Northern Gulf of Mexico deep sea. Deep-Sea Res. II 55, 2607-2616.

Balance, P.F., 1991. Gravity flows and rock recycling on the Tonga landward trench slope: Relation to trench-slope tectonic processes. J. Geol. 99, 817-827.

Belyaev, G.M., 1972. Hadal bottom fauna of the world ocean. In: Zenkevich, L.A. (Ed.), Israel Program for Scientific Translations Catalog. Israel Program for Scientific Translations, Jerusalem, p. 199.

Belyaev, G.M., 1989. Deep-Sea Ocean Trenches and Their Fauna. Nauka Publishing House, Belarus.

Blankenship, L.E., Yayanos, A.A., Cadien, D.B., Levin, L.A., 2006. Vertical zonation patterns of scavenging amphipods from the Hadal zone of the Tonga and Kermadec Trenches. Deep-Sea Res. I 53, 48-63.

Bongers, T., 1990. The maturity index: an ecological measure of environmental disturbance based on nematode species composition. Oecologia 83, 14-19.

Clarke, K.R., Warwick, R.M., 2001. Change in Marine Communities: An Approach to Statistical Analysis and Interpretation, second ed. PRIMER-E Ltd., Plymouth.
Danovaro, R., Gambi, C., Della Groce, N., 2002. Meiofauna hotspot in the Atacama Trench, eastern South Pacific Ocean. Deep-Sea Res. I 49, 843-857.

Etter, R.J., Grassle, J.F., 1992. Patterns of species diversity in the deep sea as a function of sediment particle size diversity. Nature 360, 576-578.

Feller, R.J., Warwick, R.M., 1988. Energetics. In: Higgins, R.P., Thiel, H. (Eds.), Introduction to the Study of Meiofauna. Smithsonian Institution Press, Washington, pp. 181-196.

Fonseca, G., Decraemer, W., 2008. State of the art of the free-living marine Monhysteridae (Nematoda). J. Mar. Biol. Assoc. U. K. 88, 1371-1390.

Fujii, T., Kilgallen, N.M., Rowden, A.A., Jamieson, A.J., 2013. Deep-sea amphipod community structure across abyssal to hadal depths in the Peru-Chile and Kermadec trenches. Mar. Ecol. Prog. Ser. 492, 125-138.

Gallo, N.D., Cameron, J., Hardy, K., Fryer, P., Bartlett, D.H., Levin, L.A., 2015. Submersible- and lander-observed community patterns in the Mariana and New Britain trenches: Influence of productivity and depth on epibenthic and scavenging communities. Deep-Sea Res. I 99, 119-133.

Gambi, C., Vanreusel, A., Danovaro, R., 2003. Biodiversity of nematode assemblages from deep-sea sediments of the Atacama Slope and Trench (South Pacific Ocean). Deep-Sea Res. I 50, 103-117.

George, R.Y., Higgins, R.P., 1979. Eutrophic Hadal Benthic Community in the Puerto Rico Trench. Ambio Special Report 6, 1979, pp. 51-58.

Giere, O., 2009. Meiobenthology: The Microscopic Motile Fauna of Aquatic Sediments, 2nd edition. Springer, Berlin, p. 527.

Glud, R.N., Wenzhofer, F., Oguri, K., Middelboe, M., Turnewitsch, R., Canfield, D.E., Kitazato, H., 2013. High rates of microbial turnover in sediments in the deepest oceanic trench on Earth. Nature 6, 284-288.

Grove, S.L., Probert, P.K., Berkenbusch, K., Nodder, S.D., 2006. Distribution of bathyal meiofauna in the region of the Subtropical Front, Chatham Rise, South-West Pacific. J. Exp. Mar. Biol. Ecol. 330, 342-355.

Heip, C.H.R., Duineveld, G., Flach, E., Graf, G., Helder, W., Herman, P.M.J., Lavaleye, M., Middelburg, J.J., Pfannkuche, O., Soetaert, K., Soltwedel, T., de Stigter, H., Thomsen, L., Vanaverbeke, J., de Wilde, P., 2001. The role of the benthic biota in sedimentary metabolism and sediment-water exchange processes in the Goban Spur are (NE Atlantic). Deep-Sea Res. II 48, 3223-3243.

Hurlbert, S.H., 1971. The non-concept of species diversity: a critique and alternative parameters. Ecology 52, 577-586.

Ichino, M.C., Clark, M.R., Drazen, J.C., Jamieson, A., Jones, D.O.B., Martin, A.P., Rowden, A.A., Shank, T.M., Yancey, P.H., Ruhl, H.A., 2015. The distribution of benthic biomass in hadal trenches: a modelling approach to investigate the effect of vertical and lateral organic matter transport to the seafloor. Deep-Sea Res. I $100,21-33$.

Ikehara, K., Irino, T., Usami, K., Jenkins, R., Omura, A., Ashi, J., 2014. Possible submarine tsunami deposits on the outer shelf of Sendai Bay, Japan resulting from the 2011 earthquake and tsunami off the Pacific coast of Tokohu. Mar. Geol. 358, 120-127.

Itoh, M., Kawamura, K., Kitahashi, T., Kojima, S., Katagiri, H., Shimanaga, M., 2011 Bathymetric patterns of meiofaunal abundance and biomass associated with the Kuril and Ryuku trenches, western North Pacific Ocean. Deep-Sea Res. I 58, 86-97.

Jacobs, L.J., 1987. A redefinition of the genus Monhystrella Cobb (Nematoda, Monhysteridae) with keys to the species. Zool. Scr. 16, 191-197.

Jamieson, A.J., Fujii, T., Mayor, D.J., Solan, M., Priede, I.G., 2010. Hadal trenches: the ecology of the deepest places on earth. Trends Ecol. Evol. 25, 190-197.

Jamieson, A.J., Kilgallen, N.M., Rowden, A.A., Fujii, T., Horton, T., Lorz, A.N., Kitazawa, K., Priede, I.G., 2011. Bait-attending fauna of the Kermadec Trench, SW Pacific Ocean: evidence for an ecotone across the abyssal-hadal transition zone. DeepSea Res. I 58, 49-62.

Jamieson, A.J., 2015. The Hadal Zone: Life in the Deepest Oceans. Cambridge University Press, Cambridge.

Jumars, P.A., Hessler, R.R., 1976. Hadal community structure: implications from the Aleutian Trench. J. Mar. Res. 34, 547-560.

Kitahashi, T., Kawamura, K., Kojima, S., Shimanaga, M., 2013. Assemblage gradually change from bathyal to hadal depth: A case study on harpacticoid copepods around the Kuril Trench (north-west Pacific Ocean). Deep-Sea Res. I 74, 39-47.

Lambshead, P.J.D., Tietjen, J., Glover, A., Ferrero, T., Thistle, D., Gooday, A.J., 2001 Impact of large-scale natural physical disturbance on the diversity of deep-sea North Atlantic nematodes. Mar. Ecol. Prog. Ser. 214, 121-126.

Leduc, D., Probert, P.K., Berkenbusch, K., Nodder, S.D., Pilditch, C.A., 2010. Abundance of small individuals influences the effectiveness of processing techniques for deep-sea nematodes. Deep-Sea Res. I 57, 1363-1371.

Leduc, D., 2015. One new genus and five new nematode species (Monhysterida, Xyalidae) from Tonga and Kermadec trenches, Southwest Pacific. Zootaxa 3964 501-525.

Leduc, D., Rowden, A.A., Probert, P.K., Pilditch, C.A., Nodder, S.D., Vanreusel, A., Duineveld, G.C.A., Witbaard, 2012. Further evidence for the effect of particlesize diversity on deep-sea benthic biodiversity. Deep-Sea Res. I 63, 164-169.

Leduc, D., Pilditch, C.A., 2013. Effect of a physical disturbance event on deep-sea nematode community structure and ecosystem function. J. Exp. Mar. Biol. Ecol. 440, 35-41.

Mahaut, M.L., Sibuet, M., Shirayama, Y., 1995. Weight-dependent respiration rates in deep-sea organisms. Deep-Sea Res. I 42, 1575-1582.

Meyers, M.B., Fossing, H., Powell, E.N., 1987. Microdistribution of interstitial meiofauna, oxygen and sulphide gradients, and the tubes of macro-infauna. Mar. Ecol. Prog. Ser. 35, 223-241.

Moodley, L., Chen, G., Heip, C., Vincx, M., 2000. Vertical distribution of meiofauna in sediments from contrasting sites in the Adriatic Sea: Clues to the role of abiotic versus biotic control. Ophelia 53, 203-212. 
Murashima, T., Nakajoh, H., Takami, H., Yamauchi, N., Miura, A., Ishizuka, T., 2009. In: Proceedings of the OCEANS 2009-EUROPE 11,000 m class free fall mooring system, pp. 1-5.

Nodder, S.D., Pilditch, C.A., Probert, P.K., Hall, J.A., 2003. Variability in benthic biomass and activity beneath the Subtropical Front, Chatham Rise, SW Pacific Ocean. Deep-Sea Res. I 50, 959-985.

Nomaki H., Mochizuki T., Kitahashi T., Nunoura T., Arai K., Toyokufu T., Tanaka G., Shigeno S., Tasumi E., Fujikura K. and Watanabe S., Effects of mass sedimentation events after the 2011 earthquake off the Pacific coast of Tokohu on benthic prokaryotes and meiofauna inhabiting the upper bathyal sediments, J. Oceanogr., http://dx.doi.org/10.1007/s10872-015-0293-5, in press.

Oguri, K., Kawamura, K., Sakaguchi, A., Toyofuku, T., Kasaya, T., Murayama, M., Fujikura, K., Glud, R.N., Kitazato, H., 2013. Hadal disturbance in the Japan Trench induced by the 2011 Tokohu-Oki earthquake. Sci. Rep. 3, 1915.

Piepenburg, D., Blackburn, T.H., von Dorrien, C.F., Gutt, J., Hall, P.O.J., Hulth, S., Kendall, M.A., Opalinski, K.W., Rachor, E., Schmid, M.K., 1995. Partitioning of benthic community respiration in the Arctic (northwestern Barents Sea). Mar Ecol. Prog. Ser. 118, 199-213.

Quinn, P.Q., Keough, M.J., 2009. Experimental Design and Data Analysis for Biologists. Cambridge University Press, Cambridge.

Radziejewska, T., 2002. Responses of meiobenthic communities to sediment disturbance simulating effects of polymetallic nodule mining. Int. Rev. Hydrobiol. 87, 457-477.

Rex, M.A., 1983. Geographic patterns of species diversity in the deep-sea benthos. In: Rowe, G.T. (Ed.), The sea, vol 8. Deep-Sea Biology. Wiley, New York, NY, pp. 453-472.

Rex, M.A., Etter, R.J., Morris, J.S., Crouse, J., McClain, C.R., Johnson, N.A., Stuart, C.T. Deming, J.W., Thies, R., Avery, R., 2006. Global bathymetric patterns of standing stock and body size in the deep-sea benthos. Mar. Ecol. Prog. Ser. 317, 1-8.

Richardson, M.D., Briggs, K.B., Bowles, F.A., Tietjen, J.H., 1995. A depauperate benthic assemblage from the nutrient-poor sediments of the Puerto Rico Trench. Deep-Sea Res. I 42, 351-364.

Rowe, G.T., Wei, C., Nunnally, C., Haedrich, R., Montagna, P., Baguley, J., Bernhard, J. Wicksten, M., Ammons, A., Escobar Briones, E., Soliman, Y., Deming, J.W., 2008 Comparative biomass structure and estimated carbon flow in food webs in the deep Gulf of Mexico. Deep-Sea Res. II 55, 2699-2711.

Schmidt-Rhaesa, A. (Ed.), 2014. Handbook of Zoology. Gastrotricha, Cycloneuralia 542 Gnathifera. Volume 2 Nematoda. De Gruyter, 759 pp.
Schmidt, C., Martinez-Arbizu, P., 2015. Unexpectedly higher metazoan meiofauna abundances in the Kuril-Kamchatka trench compared to the adjacent abyssal plains. Deep-Sea Res. II 111, 60-75.

Shirayama, Y., 1984a. The abundance of deep sea meiobenthos in the Western pacific in relation to environmental factors. Ocean. Acta 7, 113-121.

Shirayama, Y., 1984b. Vertical distribution of meiobenthos in the sediment profile in bathyal, abyssal, and hadal deep sea systems of the Western Pacific. Ocean. Acta 7, 123-129.

Shirayama, Y., Kojima, S., 1994. Abundance of deep-sea meiobenthos off Sanriku, Northeastern Japan. J. Ocean. 50, 109-117.

Smith, C.R., 1992. Factors controlling bioturbation in deep-sea sediments and their relation to models of carbon diagenesis. In: Rowe, G.T., Pariente, V. (Eds.), DeepSea Food Chains and the Global Carbon Cycle. Kluwer Academic Publishers, Germany, pp. 375-393.

Somerfield, P.J., Warwick, R.M., 1996. Meiofauna in Marine Pollution Monitoring Programmes: A Laboratory Manual. Ministry of Agriculture, Fisheries and Food, Lowestoft, $71 \mathrm{pp}$.

Tietjen, J.H., 1989. Ecology of deep-sea nematodes from the Puerto Rico Trench area and hatteras Abyssal Plain. Deep-Sea Res. 36, 1579-1594.

Tietjen, J.H., Deming, J.W., Rowe, G.T., Macko, S., Wilke, R.J., 1989. Meiobenthos of the Hatteras Abyssal Plain and Puerto Rico Trench: abundance, biomass and associations with bacteria and particulate fluxes. Deep-Sea Res. 36, 1567-1577.

Vanhove, S., Vermeeren, H., Vanreusel, A., 2004. Meiofauna towards the South Sandwich Trench (750-6300 m), focus on nematodes. Deep-Sea Res. II 51, 1665-1687.

Vanreusel, A., Fonseca, G., Danovaro, R., da Silva, M.C., et al., 2010. The contribution of deep-sea macrohabitat heterogeneity to global nematode diversity. Mar. Ecol. 31, 6-20.

Warwick, R.M., Platt, H.M., Somerfield, P.J., 1998. Free Living Marine Nematodes. Part III. Monhysterids. Synopses of the Brithsh Fauna (New Series). 53. Cambridge University Press, Cambridge, p. 296.

Watling, L., Guinotte, J., Clarke, M.R., Smith, C.R., 2013. A proposed biogeography of the deep ocean floor. Prog. Ocean. 18, 529-551.

Wenzhofer, F, Glud, R. et al. (this issue).

Wolff, T., 1960. The hadal community, an introduction. Deep-Sea Res. 6, 95-124.

Wolff, T., 1970. The concept of the hadal or ultra-abyssal fauna. Deep-Sea Res. 17, 983-1003. 